\title{
Scaling up asset-building programs for marginalized adolescent girls in socially conservative settings: The Ishraq program in rural Upper Egypt
}

\author{
Nadia Zibani \\ Population Council \\ Martha Brady \\ Population Council
}

Follow this and additional works at: https://knowledgecommons.popcouncil.org/departments_sbsr-pgy

Part of the Demography, Population, and Ecology Commons, Family, Life Course, and Society

Commons, Gender and Sexuality Commons, and the International Public Health Commons

How does access to this work benefit you? Let us know!

\section{Recommended Citation}

Zibani, Nadia and Martha Brady. 2011. "Scaling up asset-building programs for marginalized adolescent girls in socially conservative settings: The Ishraq program in rural Upper Egypt," Promoting Healthy, Safe, and Productive Transitions to Adulthood Brief no. 12. New York: Population Council. 


\section{Scaling up asset-building programs for marginalized adolescent girls in socially conservative settings: The Ishraq program in rural Upper Egypt}

\section{Prepared by Nadia Zibani and Martha Brady}

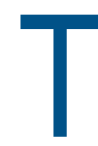
he years of transition from childhood to adulthood are often defined by expanding opportunities, growing self-awareness, and increased knowledge about the world. For girls in rural Egypt, the opposite can be true. As girls reach puberty, their world becomes increasingly confined to the home, their opportunities limited to household chores, and their future prospects restricted to early marriage.

Many adolescent girls in rural Upper Egypt are never enrolled in school or are forced to leave school early, circumstances that relegate them to a life of diminished opportunities. Out-of-school girls are among the most disadvantaged adolescents in rural Egypt. Compared with girls attending school, they are more likely to be engaged in poorly paid farm work, are more likely to be married off early, and are at greater risk for a number of adverse health events, including malnutrition, early childbearing, and poor pregnancy outcomes (El Tawila et al. 1999).

According to the Egyptian Labor Market Panel Survey of 2006 (Barsoum 2006), 26 percent of Egyptian girls aged 13-19 in Upper Egypt either received no schooling or dropped out after just one or two years. Each passing year spent out of school makes a lifetime of illiteracy and poor economic prospects more likely. Low levels of education also leave girls without the requisite knowledge, autonomy, and self-confidence to oppose practices that they might otherwise resist, such as female genital mutilation/cutting (FGM/C) and early marriage.

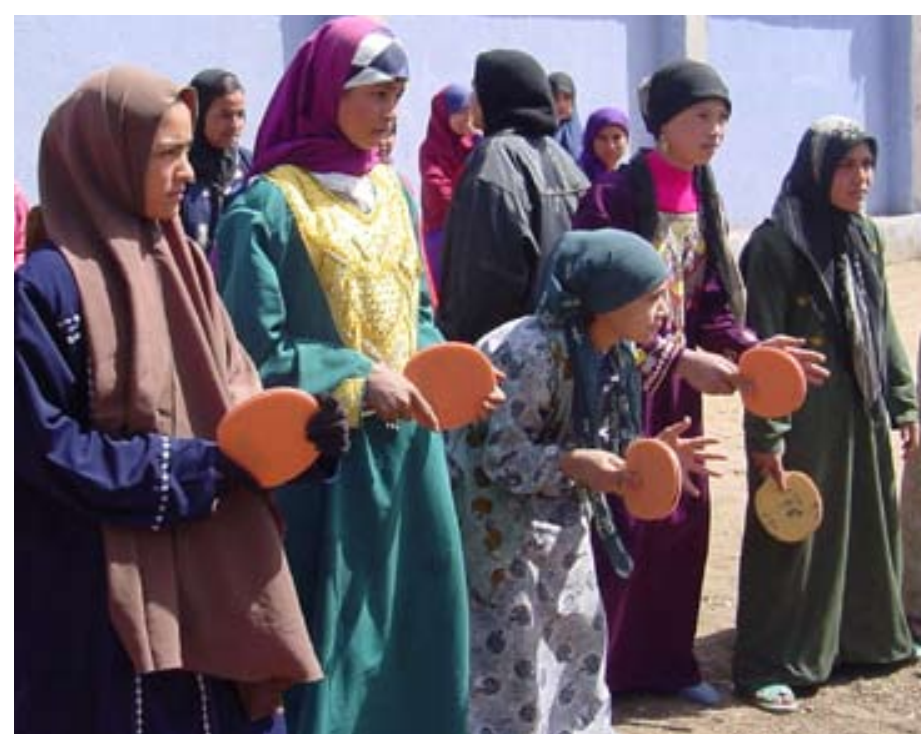

Pushing boundaries but not transgressing norms: Girls participate in sports for the first time.

Given the problems faced by adolescent girls who are deprived of school and live in traditional and conservative settings, programs are needed that provide resources and training, foster social development, and empower girls to have greater say in their lives and their communities. At the same time, efforts are needed to foster public and institutional support for new and expanded roles for girls. 
The Ishraq program: Promoting learning, literacy, and life skills to build girls' capacities and agency

In 2001, the Population Council and Save the Children, in partnership with Caritas and the Centre for Development and Population Activities (CEDPA; now TFD), pooled their expertise to design and implement an intervention program to address the needs of out-of-school adolescent girls in rural Upper Egypt. The pilot intervention, referred to locally as Ishraq ("sunrise" in Arabic), was launched in four rural villages of el-Minya governorate in Upper Egypt, which is the country's least developed and most disadvantaged region. Targeting girls aged 13-15, this holistic program was designed to promote literacy, impart life skills, build social networks, and foster leadership and self-confidence through sports. By establishing girl-friendly spaces in which program participants could meet, learn, play, and work collectively, the program sought to safely and confidently bring girls into the public space. At the same time, related interventions aimed at girls' gatekeepers-parents, boys, and community leaders-were designed to initiate change in community norms and beliefs about the capacities and roles of girls in society.

The Ishraq program consists of literacy training, a broadly defined life-skills curriculum, and, for the first time in rural Upper Egypt, sports activities to enhance leadership and team-building skills and prepare girls for integration into formal schooling. For 24 months, girls meet approximately four times each week for three-hour sessions at youth

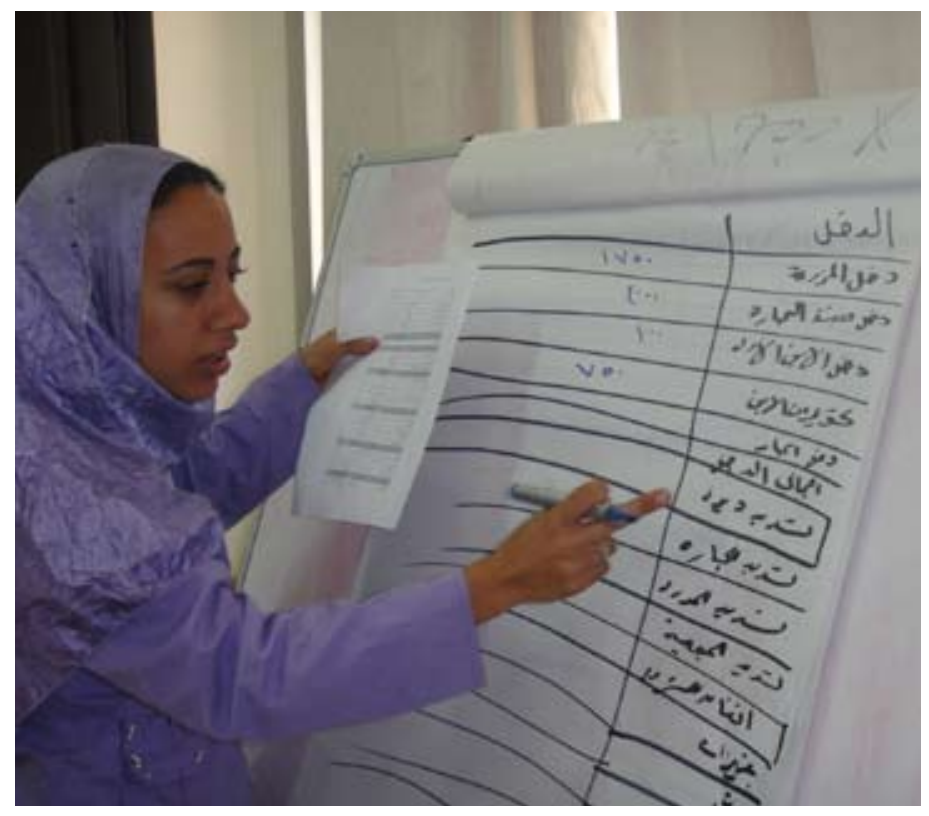

Learning new skills—both numeracy and financial literacy—helps girls move forward. centers, in groups of approximately 25-30 girls each. "Program promoters," young women who have graduated from secondary school, are recruited from the community and trained to serve as teachers and mentors to participating girls and to lead activities, thereby lending credibility to the program. Ishraq also benefits from the support of the National Council for Youth (NCY), which has designated unprecedented "girls-only" time at the village youth centers, thereby creating a "safe space" for these groups to meet.

The Ishraq curriculum consists of mathematics, reading and writing in Arabic, and a life-skills component that provides information on reproductive health, citizenship, rights, and the opportunity to participate in sports. The approach emphasizes active participation and dialogue. Teachers introduce a topic, often through a picture, video, or song, to stimulate discussion. Girls use newly introduced skills, such as spelling, word definition, and problem/answer articulation, to explore the topic. The participatory nature of the curriculum is enhanced by a physical activities component. Girls don track suits to participate in sports, many of them for the first time in their lives.

For the past decade, the Ishraq program has focused primarily on building literacy and social skills for girls in rural communities. More than 900 girls have graduated from Ishraq in 14 communities located in the two Upper Egyptian governorates of el-Minya and Beni-Suef. Based on a successful pilot, Ishraq began moving into the next phase, which included recruiting younger girls into the program and strengthening the program content to include financial literacy.

Extending the benefits of the program for Ishraq graduates: Creating girls' clubs

In 2008, the Council established Girls' Clubs in two villages in el-Minya targeting close to 70 graduates from the pilot phase. These Girls' Clubs were led by former Ishraq promoters who have since become leaders in their communities. Each Girls' Club is comprised of 20 Ishraq graduates who meet twice a week at the youth center. Many graduates have remarked that "Youth centers are where we (as Ishraq girls) had the best memories of our lives."

The Girls' Clubs provide: 1) financial support to the graduates to continue their formal education in middle and secondary schools (around 74 percent of all program participants attended school after their graduation from /shraq); 2) pilot-testing of a new financial education curriculum, Microfinance Opportunities, that is being integrated into the scale-up phase of Ishraq being implemented in 30 villages; and 3) legal rights awareness training to raise girls' awareness, legal understanding, and capabilities, and increase linkages to other community services. The legal rights training includes discussion of official 
documents (birth certificates and ID cards), personal status laws (engagement, marriage, divorce, and custody), the new Egyptian child laws and family justice project, and violence against girls/women, including FGM/C. Most of the Ishraq participants reported that the legal rights training was extremely valuable.

In 2010, the Girls' Club model was replicated in an additional four villages each in el-Minya and Beni-Suef targeting 215 graduates.

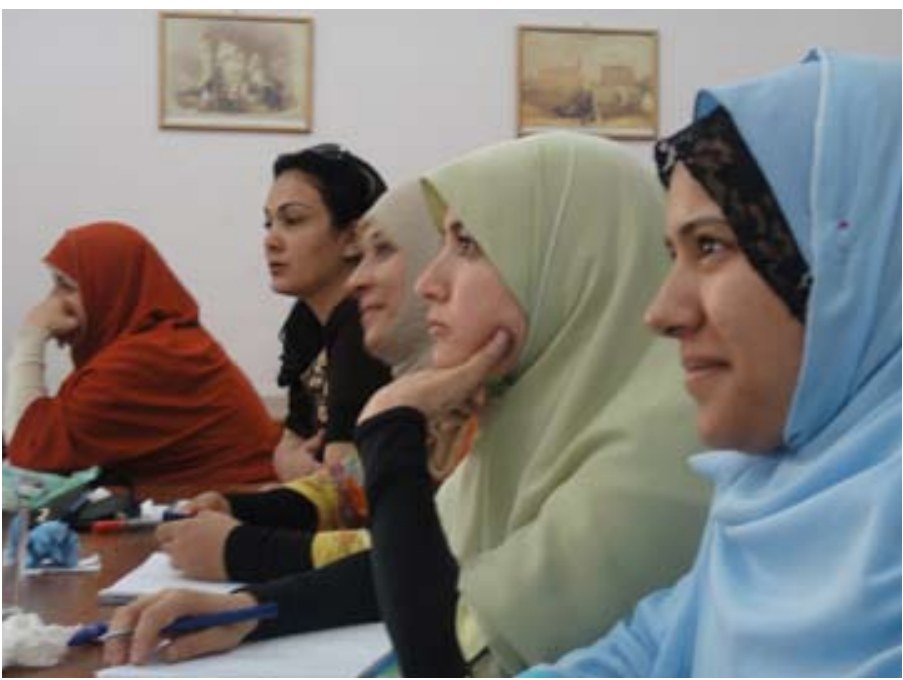

Ishraq graduates continue to learn and gain skills.

These new Girls' Clubs, ranging in size from 21 to 33 participants, were led by former Ishraq promoters. Participants were largely selfselected and were recruited through the promoters. The proportion of non-Ishraq participants was 38 percent, the majority of whom were in school.

\section{Building financial literacy and legal rights knowledge}

In 2008, the Council collaborated with Microfinance Opportunities in Cairo to provide financial education master training to former Ishraq "program promoters." Upon completion of this training, the promoters piloted the financial education curriculum, which consists of modules on budgeting, savings, debt management, bank services, and financial negotiations, with a group of 70 Ishraq graduates. Field testing of the financial education curriculum was completed in December 2009, helping to clarify and strengthen the curriculum and its delivery model for scale-up within the Ishraq program. An important component of the pilot was creating an incentive for girls to apply their knowledge by opening individual savings accounts at the post office in their village and to begin saving. Former Ishraq "program promoters" are preparing to deliver financial education to approximately 200 girls located in eight villages of el-Minya and in Beni-Suef. The next step will be to promote and scale-up a financial education curriculum to the larger group of beneficiaries currently participating in Ishraq in 30 rural communities located in governorates of Fayoum, Sohag, and Qena.

\section{From pilot to scale}

The NCY and the National Council for Childhood and Motherhood (NCCM) have embraced Ishraq as an important program model. International partners, with the collaboration of NCY and NCCM, are expanding Ishraq activities into three of the poorest and most socially conservative Egyptian governorates. In 2009, the successful Ishraq pilot program began an ambitious scale-up effort to reach girls living in 30 villages in Fayoum, Sohag, and Qena. In addition, 120 secondary school graduates were recruited and trained as Ishraq program leaders to serve as teachers, role models, and advocates.

The program currently targets girls $13-15$ years of age, but younger girls benefit from the program as well; for example, 23 percent of participants are 12 years old. In many of the communities where Ishraq is being implemented, there is high demand among girls as young as 11 to participate.

\section{"Ishraq fulfilled our dreams to be educated and respected by our families and our communities."}

-Ishraq participant

\begin{abstract}
"For the first time in my life, I learned that girls have equal rights to education as boys. In the past, my understanding was that girls did not need to be educated because they were going to marry."
\end{abstract}

-Ishraq participant

Furthermore, the Ishraq program is helping to get girls into school. Upon completion of the 24-month Ishraq program, girls who passed the official government literacy examination (the GALAE) are eligible to enter the formal education system as long as they are younger than 18 years old. In 2011, 1,531 girls who participated in Ishraq took the GALAE, the first step toward entering formal education.

The Ishraq program has shown that it is possible to reach girls in traditionally conservative areas and encourage them to attend school, question social norms, and think about their futures in ways they have not done before. 


\section{References and related publications}

Barsoum, Ghada. 2006. Egypt Labor Market Panel Survey 2006, Final Report. Cairo: Population Council.

Brady, Martha, Ragui Assaad, Barbara Ibrahim, Abeer Salem, Rania Salem, and Nadia Zibani. 2007. Providing New Opportunities to Adolescent Girls in Socially Conservative Settings: The Ishraq Program in Rural Upper Egypt. New York: Population Council.

El Tawila, Sahar, Omaima el-Gibaly, Barbara Ibrahim, Fikrat el-Sahn, Sunny Sallam, Susan M. Lee, Barbara Mensch, Hind Wassef, Sarah Bukhari, and Osman Galal. 1999. Transitions to Adulthood: A National Survey of Adolescents in Egypt. Cairo: Population Council.

El-Roubi, Dina Saad. 2011. "A comparative study between the Ishraq pilot program and scale up," Population Council Report.

El-Zanaty, Fatma and Ann Way. 2009. Egypt Demographic and Health Survey 2008. Cairo and Calverton, MD: Ministry of Health, El-Zanaty and Associates, and Macro International.

\section{Donors}

Department for International Development (DFID), Bill \& Melinda Gates Foundation, The Ford Foundation, The Dickler Family Fund, Nike Foundation, The Netherlands Embassy in Cairo, EMPower-The Emerging Markets Foundation, The H.B. Fuller Company Foundation.

\section{Partner institutions}

Caritas-Egypt

Teaming for Development (formerly CEDPA)

The Egyptian Food Bank

The National Council for Youth

The Minister of State for Population and Family

Local nongovernmental organizations

\section{(2) Population Council}

The Population Council changes the way the world thinks about critical health and development issues. We seek to understand the causes and consequences of gender inequality and the disparities in opportunity that arise during adolescence. We provide the evidence for better on-theground programs and policies that ensure successful and productive transitions to adulthood in developing countries. www.popcouncil.org

๑) 2011 The Population Council, Inc.

4 - Visit www.popcouncil.org/publications/serialsbriefs/TABriefs.asp for all briefs in the Promoting healthy, safe, and productive transitions to adulthood series. 